\title{
OKTATÁSI REFORMOK ÉS TANÜGYIGAZGATÁS LENGYELORSZÁGBAN
}

\author{
VELKEY KRISTÓF \\ ELTE PPK Neveléstudományi Doktori Iskola \\ Uniwersytet Warszawski Wydział Pedagogiczny
}

A tanulmány a lengyelországi tanügyigazgatás hangsúlyváltozásait mutatja be. Arra keresi a választ, hogy hogyan alakult, és milyen tényezők formálták az állam és önkormányzatok közötti feladatmegosztást az elmúlt harminc évben. Az önkormányzatok a kilencvenes években fokozatosan vették át a fenntartói feladatokat az államtól, ezzel párhuzamosan a középszintű regionális állami oktatásirányítási szerv, a kuratorium oświaty szerepe is átalakult. Az 1999-es rendszerszintű reform során a kuratoriumok és önkormányzatok viszonya, feladatkörei nem kerültek tisztázásra. Az eredetileg csak a müködtetői feladatokért felelős önkormányzatokra egyre több felelősség hárult az oktatás minőségével kapcsolatban, mely eredetileg a kuratoriumok feladata volt. Ezzel párhuzamosan ez utóbbiak hatalma és feladatkörei a 2000-es években tovább csökkentek, később a megszüntetésük is felmerült. 2015-ben viszont újabb rendszerszintü oktatási reform indult meg, melynek során a folyamat megfordult. A jelenlegi kormány a kuratoriumok szerepének erősítésével az állam oktatási szerepét erősíti.

Kulcsszavak: Lengyelország, tanügyigazgatás, decentralizáció, kontroll

The study presents the various changes in the governance of the Polish education system. It focuses on how the division of responsibilities between the state and local governments changed and what factors have shaped it over the past thirty years. After 1990 the local governments gradually took over the maintenance of elementary and secondary schools from the state, while the role of the regional public education management body, the kuratorium oświaty, which was responsible for the maintenance before was transformed parallelly. During the 1999 whole system education reform the relationship and responsibilities of the kuratoriums and local governments were not defined clearly. The local governments, which were initially responsible mainly for maintenance tasks, became increasingly responsible for the quality of education, which was originally the responsibility of the kuratoriums. At the same time the authority and responsibilities of the latter were further reduced in the 2000s, their dissolution came up as well. In 2015, however, another systemic education reform was launched, revolutionizing the process.

Levelező szerző: Velkey Kristóf, 3530 Miskolc, Meggyesalja u. 4. fszt. 3. E-mail: kristof.velkey@gmail.com 
The current government is strengthening the role of the state in educational governance by broadening the responsibilities of kuratoriums.

Keywords: Polish Education System, Education governance, decentralisation, accountability

\section{Bevezetés}

L engyelországban a rendszerváltást követően az önkormányzatok váltak felelőssé az oktatási intézmények fenntartásáért, az állam azonban saját hatáskörben tartotta az oktatás kereteinek meghatározását és az intézmények feletti pedagógiai kontrollt, melyet a regionális szintre dekoncentrált állami oktatásirányításon, a kuratorium oświatyn ${ }^{1}$ keresztül lát el. Tanulmányomban a lengyel oktatási rendszerben jelen levő decentralizáció (önkormányzat mint fenntartó) és centralizáció (kuratorium mint a kormányzat helyi képviselője és a pedagógiai felügyelet ellátója) kettősségét és ennek hatásait vizsgálom a témával foglalkozó lengyel és angol nyelvü szakirodalomra, továbbá szakértőkkel (SZ) és minisztériumi vezetőkkel (M) készült interjúkra támaszkodva, melyeket doktori kutatásom során készítettem.

Először áttekintem a lengyel rendszert meghatározó oktatáspolitikai változásokat és reformokat a decentralizáció szempontjából meghatározó kilencvenes évek változásaira visszatekintve, majd részletesen bemutatom a lezajlott decentralizációs folyamatot és hatásait, a kuratoriumok szerepének változását, és felvázolom a lengyel oktatásfinanszírozás jellegzetességeit is.

\section{Oktatási reformok Lengyelországban}

A lengyel oktatáspolitika irányát meghatározzák a politikai változások, a kormányváltások általában újabb reformokat hoznak magukkal. A politikusok elköteleződése az oktatás mellett leginkább deklarációkban jelenik meg. Az oktatás általában limitált költségvetési forrásokkal rendelkezik, az oktatási miniszterek rendszerint nem tartoznak a legbefolyásosabb politikusok közé (Zahorska 2016), vagy nem is pártpolitikusok, hanem az egyetemi szférából érkező szakemberek, esetleg tanárok (SZ1).

A kilencvenes évek lengyel oktatását vég nélküli viták és reformtervek jellemezték. Először Mirosław Handke rendelkezett megfelelő politikai támogatással (SZ4) a reformtervei megvalósításához. Az oktatási rendszert alapjaiban átalakító 1999-es reform során az oktatásirányítás decentralizációja mellett többek közt új iskolastruktúra, vizsgarendszer, új alaptanterv és tanári előmeneteli rendszer került bevezetésre. A reform célja a lengyel társadalom iskolázottsági szintjének javítása volt, az egyenlőtlenségek kiegyenlítésére fókuszált, mindenki számára biztosítani kívánta a minőségi általános oktatást (Handke 2015). Központi eleme az általános képzés meghosszabbítása volt: bevezetésre került az általános iskola 6. osztályát követő gimnazjum (alsó középiskola), mely továb-

1 A dolgozatban törekszem az eredeti lengyel elnevezések használatára, ugyanis a magyar fordítás más jelentéstartalmat hordoz. A kuratorium például elsőre a magyar tankerületnek felelhetne meg, azonban Lengyelországban a szervezet a kilencvenes évek vége óta nem lát el fenntartói feladatokat, mely a jelenlegi magyar oktatási rendszerben a tankerületi központok legfőbb feladatköre. 
bi hároméves egységes általános képzést biztosított. A felső középiskolák tervezett reformja a 2002-es kormányváltást követően más formában valósult meg, és megmaradtak a reform előtt létező intézménytípusok.

Katarzyna Hall minisztersége alatt 2007-től indult meg egy újabb reformfolyamat, melynek a célja az 1999-es reform felülvizsgálata és befejezése volt (SZ4; M1). A reform része volt az alaptanterv és a vizsgarendszer kapcsolatának felülvizsgálata új alaptanterv bevezetésével, illetve a szakfelügyeleti és iskolaértékelési rendszer átalakítása. A reformok között politikailag legmeghatározóbb a tankötelezettség 6 éves korra való leszállításának kudarca volt, mely az erős társadalmi ellenállás hatására többször eltolva került bevezetésre, majd a 2015-ös kormányváltást követően visszaállították 7 éves korra.

Sadura (2017) a lengyel oktatási rendszerben 1999 és 2015 közötti változásokat a nyugati országokban a kilencvenes években lezajlott folyamatokhoz hasonlítja, mint az oktatási piac létrejötte, a mérés- és értékelési technikák elterjedése és a piaci eszközök megjelenése az oktatásirányításban és finanszírozásban.

A 2015-ben kormányra került Jog és Igazságosság Párt (Prawo i Sprawiedliwość) a társadalmi igényekre hivatkozva, választási ígéreteinek megfelelően, a kormányváltás után egyből hozzáfogott az oktatási rendszer átalakításához, melynek központi eleme volt a nyolcosztályos általános iskola és a hagyományos négyéves középiskolai képzés viszszaállítása, az 1999-ben bevezetett alsó középiskolák megszüntetésével. A reform célja Zahorska (2016) szerint a lengyel oktatás tradicionális értékeihez való visszatérés volt. Ez látható Beata Szydło (2015) miniszterelnök parlamenti nyitóbeszédében is, aki a tervezett oktatási változásokkal kapcsolatban kiemelte, hogy a lengyel oktatás tesztközpontúsága helyett a tudásközpontúságot és a nemzeti, hazafias nevelést kell a középpontba állítani, a szakképzési rendszert pedig a gazdasági igényeknek megfelelően kell átalakítani a vállalkozókkal együttmüködve.

A reform előkészítése és bevezetése is nagyon gyorsan történt. Az előkészületek 2015 végén kezdődtek meg, és egy évre rá, 2016 decemberében már a parlament el is fogadta az új oktatási törvényt (Ustawa $z$ dnia 14 grudnia 2016. r. Prawo Oświatowe). Ugyanakkor az eddigi oktatási rendszerről szóló törvény (Ustawa $z$ dnia 7 września 1991 r. o systemie oświaty) vizsgarendszert, a diákok előmenetelét, tankönyveket és az oktatás finanszírozását érintő részei továbbra is érvényben maradtak, bár ez utóbbit 2018 óta külön törvény szabályozza (Ustawa z dnia 27 października 2017 r. o finansowaniu zadań oświatowych). Emellett továbbra is érvényes maradt a közoktatásban dolgozó tanárok munkáját és jogállását szabályozó Karta Nauczyciela (Ustawa z dnia 26 stycznia 1982 r. Karta Nauczyciela). A törvényi változások nem jártak az oktatási törvény teljes megújításával, az új szabályozás többségében az elöző törvény tartalmát ismétli meg, sok esetben csak áthelyezve az egyes szakaszokat (Pilich-Olszewski 2018).

Az új oktatási törvény 2017 januárjában került kihirdetésre. A törvény rendelkezései és az iskolai szerkezetváltás 2017. szeptember elsejétől kerül bevezetésre felmenő rendszerben. A szerkezeti változásokkal együtt járt az alaptanterv átalakítása és a vizsgarendszer változása is. Az új kerettantervek kidolgozása és véleményezése feszített tempóban 2016 végén valósult meg, hogy 2017 szeptemberétől már az új kerettantervnek megfelelő tankönyvekből tudjanak tanulni az első, negyedik és hetedik évfolyamon a diákok.

A 2018/2019-es tanévben végez az utolsó gimnazjumi évfolyam, ezzel párhuzamosan az általános iskola hatodik évfolyamán tanuló diákok a hetedik évfolyamon folytatták 
a tanulmányaikat 2017 szeptemberében. Idén ért össze a két rendszer, a 2019/2020-as tanévben egyszerre két évfolyam kezdi el majd a középfokú tanulmányait, jelentős feszültségeket okozva a rendszerben, ugyanis a középiskolák egyszerre indítanak három és négy évfolyamos osztályokat, így az iskolák limitált befogadóképességéből fakadóan hatalmas verseny várható a jobb középiskolákba való bejutásért. ${ }^{2}$

Eddig a gimnazjum elvégzése után 3 éves felső középiskolában (liceum ogólnokształcace), 4 éves szakközépiskolában (technikum) vagy 3 éves szakképző iskolában (zasadicza szkoła zawodowa) lehetett továbbtanulni, míg a most bevezetés alatt álló rendszerben a nyolcosztályos általános iskolát követően válnak el a különböző képzési utak: 4 éves általános középiskola (liceum); 5 éves szakközépiskola (technikum); illetve a két képzési szintből álló szakképzés, mely egy 3 éves szakképző iskolából (brazowa szkoła I stopnia) és egy erre épülő 2 éves szakképzésből áll (brazzowa szkoła II stopnia).

$\mathrm{A} z$ előző rendszerben a hatosztályos általános iskolát lezáró vizsga hivatalosan csak felmérő szerepet töltött be, míg a gimnazjumot lezáró vizsga eredményei beleszámítottak a felső középiskolába való felvételibe. A két vizsga helyét az új nyolcosztályos általános iskolát lezáró vizsga vette át, amelynek az eredményeitől függ a továbbtanulás középfokon. Az elsőfokú szakképző iskola (brazzowa szkoła I stopnia) a szakmai ismereteket számon kérő vizsgával zárul. A másodfokú szakképző iskola bevezetése 2020-ban várható. Tervezetten a technikumhoz és liceumhoz hasonlóan érettségivel zárul, ahol a három kötelező tárgy (lengyel nyelv, idegen nyelv, matematika) mellett az adott szakma tárgyából is le kell vizsgázni.

\section{Decentralizáció}

A rendszerváltást követően a lengyel tanügyigazgatást két lényeges tényező formálta: a decentralizált, segítő állam képe, és az igény, hogy az állam megőrizze a kontrollt az oktatás minőségéhez kapcsolódó döntésekben (Herbst et al. 2015). A decentralizációs folyamat során a fenntartói és financiális feladatokat, jogköröket önkormányzati hatókörbe rendelték, így önkormányzati szintü decentralizációról beszélhetünk (Herczyński 2012), míg pedagógiai szempontból az intézmények jelentős autonómiát kaptak, állami kontrollal.

Először 1990-ben az óvodák fenntartását kapták meg a helyi önkormányzatok, melyhez nem kaptak külön forrásokat, így ez óvodabezárásokhoz, a férőhelyek csökkenéséhez vezetett (Sadura 2017). Az általános iskolákat 1993-tól vehették át önkéntes alapon az önkormányzatok, melyek fenntartása 1996-tól vált kötelező feladatukká. Ugyanekkor nyílt lehetőség városok számára a középfokú intézmények átvételére.

A fenntartói feladatok átadásával párhuzamosan 1989-től kísérleti jelleggel megindultak az első magániskolák, melyek jogállását is szabályozta az 1991-es oktatási törvény. A kilencvenes években lezajlott „piacosodás” legfőbb elemei a szabad iskolaválasztás és a nem állami vagy önkormányzati fenntartású intézmények közfinanszírozásának szabályozása volt (Levitas-Herczyński 2002).

Az 1991-es törvény megteremtette a különböző társadalmi csoportok oktatási ügyekbe való bevonásának lehetőségét is intézményi, önkormányzati, vajdasági és országos oktatási tanács létrehozásával. Ennek lehetősége azóta is megmaradt, azonban számuk

\footnotetext{
2 A középiskolai felvételi eredményei a kézirat lezárása után kerülnek nyilvánosságra.
} 
rendszerszinten nem jelentős. Összesen két vajdasági szintű tanács működik (Śliwerski 2015), mely nem elegendő az országos tanács összehívásához.

A rendszerváltás utáni reformátorok elképzelése szerint az önkormányzatok az intézmények működtetéséért feleltek, az állam feladata az oktatás kereteinek meghatározása, a pedagógiai kontrollt pedig a kuratorium látta el (Levitas-Herczyński 2012). Kezdetben ebből a feladatmegosztásból és az állami források jelenlétéből fakadóan „az önkormányzatok közömbösek voltak az iránt, hogy az igazgatók hogyan költik el az iskola működésére a költségvetésben előirányzott összeget, és az iskolák milyen minőségű szolgáltatást nyújtanak. Nem meglepő, hogy az önkormányzatok inkább az oktatási létesítményeik fizikai infrastruktúrájának javítására és a tanárok fizetésének kiegészítésére koncentrálták energiáikat" (Levitas-Herczyński 2002: 48). Ugyanakkor az önkormányzatok oktatási ügyekhez való hozzáállása már a kilencvenes években változásnak indult, az önkormányzatok egyre aktívabb szerepet játszottak a helyi oktatáspolitika alakításában. Ebben szerepet játszott, hogy az önkormányzatoknak egyre nagyobb mértékben kellett az állami szubvención felül saját forrásokat is fordítani az oktatási feladatok ellátására, ami érdekeltté tette őket a források hatékonyabb felhasználásában. Ezentúl az oktatási intézmények minősége iránti növekvő választói igények is az önkormányzat minőségi kérdésekbe való aktívabb bekapcsolódását eredményezte (Levitas-Herczyński 2012).

Az 1999-es oktatási reform szorosan összekapcsolódott a lengyel közigazgatás reformjával. ${ }^{3} \mathrm{~A}$ reform során háromszintű területi önkormányzati rendszer jött létre, ${ }^{4} \mathrm{az}$ egyes önkormányzati szinthez rendelt fenntartói feladatok az 1. táblázatban láthatóak.

A strukturális átalakítások és a frissen felálló powiatok esetén az intézmények átvétele komoly kihívás elé állította az önkormányzatokat. Több szakértő szerint (SZ1; SZ3) ezeknek a kezdeti nehézségeknek fontos szerepük lehetett abban, hogy a legtöbb esetben az önkormányzatok az iskolák ,jó gazdáivá” váltak, komolyan invesztálva az intézmények fejlesztésébe. A fenntartói feladatok ugyanakkor erősen formálták is az önkormányzatokat, melyeknek kiadásaikat és társadalmi szerepüket tekintve is ez az egyik legnagyobb feladatuk (Herbst-Herczyński 2015).

A közigazgatási reform ugyanakkor az iskolaszerkezet szempontjából az oktatási reform célkitüzéseivel ellenkező hatást váltott ki. Az 1999-es reform tervezésekor a gimnazjumokat a középfokú oktatás részeként képzelték el, önálló intézményként vagy középiskolával együttmüködésben, ${ }^{5}$ azonban a gimnazjumok és középiskolák különböző fenntartókhoz kerültek, ami megnehezítette a két iskolatípus közötti együtt-

3 Az 1997-2001 között az Akcja Wyborcza Solidarność vezetésével kormányzó jobbközép koalíció 1999. ben az oktatás és közigazgatás mellett az egészségügyben és a nyugdíjrendszerben is átfogó reformokat indított.

4 Az egyes önkormányzati szintek különböző magyar fordításaival találkoztam, melyek használata inkább félreértésekre adna okot. A gmina a legkisebb közigazgatási egység, mely a magyar községgel szemben több településből is állhat. A powiat megyei szintű önkormányzatnak, míg a 16 wojewódctwo regionális szintű önkormányzatnak feleltethető meg. A három önkormányzati szint egymástól független, kapcsolatuk nem hierarchikus. 2016-ban a 2478 gmina átlagos lakossága 15511 fö, a 314 powiat átlagos lakossága 82221 fó és a 66 powiat jogú város átlagos népessége 191212 fő volt (GUS 2016).

5 A különböző típusú intézmények a fenntartó döntése alapján iskolakomplexumba (zespół szkół) szerveződhetnek, és az így müködő intézmények közös épületekben, közös vezetés alatt müködnek közös tanári karral, és tulajdonképpen egy szervezetet alkotnak (Herczyński-Sobotka 2017), mely együttmüködési formát az egyik szakértő a lengyel oktatási rendszer egyik alulértékelt jellemzőjeként írt le (SZ3). 
1. táblázat: Az önkormányzatok intézményfenntartói feladatai a 2016-os reformot megelőzően

\begin{tabular}{|c|c|c|}
\hline Gmina & Powiat & Wojewódctwo \\
\hline $\begin{aligned} \text { - } & \text { Óvoda } \\
\text { - } & 6 \text { éves általános iskola } \\
\text { - } & 3 \text { éves alsó középiskola } \\
& \text { (gimnazjum) }\end{aligned}$ & $\begin{array}{l}\text { Érettségit adó felsö középfokú } \\
\text { intézmények: } \\
\text { _ } 3 \text { éves általános közép- } \\
\text { iskola (Liceum ogólnok- } \\
\text { ształcące) } \\
\text { - } 3 \text { éves specializált közép- } \\
\text { iskola (Liceum profilo- } \\
\text { wane) }{ }^{\text {a) }} \\
\text { - } 4 \text { éves technikum } \\
\text { Érettségit nem adó szakképzés } \\
\text { - } 3 \text { éves szakiskola } \\
\text { (Zasadnicza szkoła } \\
\text { zawodowa) }\end{array}$ & $\begin{array}{l}\text { - } \text { pedagógiai munkát támo- } \\
\text { gató intézmények (vajda- } \\
\text { sági pedagógiai könyvtár } \\
\text { és tanártovábbképző } \\
\text { központ) } \\
\text { - regionális vagy orszá- } \\
\text { gos hatókörü speciális } \\
\text { iskolák }{ }^{b}\end{array}$ \\
\hline
\end{tabular}

a) Az intézménytípus 2012-től megszűnt, az intézményben az általános képzésen túl a diákoknak lehetőségük volt megismerkedni egy szakma alapjaival, melyből az érettségi után szakképzettséget szerezhettek, szakterülettől függően 1-2 éves középiskolán túli szakképzéssel.

b) Egyes speciális és szakképző intézmények többször fenntartót váltottak 1999 óta. Jelenleg a powiat, wojewódczwo és az adott szakminisztériumok is tarthatnak fenn ilyen intézményeket, például a művészeti iskolák a kulturális minisztérium fenntartásában maradtak (Kurzyna-Chmiel 2018).

működést (SZ3). Herczyński egy interjúban (Suchecka 2016) két okot emelt ki, hogy a gimnazjumok nem a powiatok fenntartásába kerültek a reform során. Egyrészt a powiatok újonnan létrehozott szintként nem voltak felkészülve egy új intézménytípus létrehozására, másrészt a gminák rendelkeztek inkább a megfelelő infrastrukturális lehetőségekkel.

$\mathrm{Az}$ 1999-es reform tervezésekor hangsúlyos elem volt, hogy az újonnan bevezetett alsó középiskolákat különválasszák az általános iskoláktól, ez azonban nem valósult meg. A strukturális változásokkal kapcsolatos nehézségek és az önkormányzatok ellenállása miatt a törvény végül átmenetileg lehetővé tette az általános iskolák melletti müködést (egy épületben), és hogy gimnazjumi osztályok indulhassanak az általános iskolákban (Sobotka 2016). A 2002-es kormányváltás után már nemcsak átmenetileg engedélyezték, hogy egymás mellett működjenek az általános iskolák és gimnazjumok, hanem azt is lehetővé tették, hogy hivatalos együttmüködésben (zespół szkółként) müködjenek tovább. Hosszú távon ennek következményeként - a reformátorok céljaival épp ellenkezően sok helyen általános iskolával közös iskolakomplexumban működő alsó középiskolák jöttek létre. A 2012/2013-as tanévben például az alsó középiskolák 36,2 százaléka müködött önálló intézményként, míg 46,2 százaléka általános iskolával közösen müködött, melyek kialakulásához az önkormányzatok független döntései vezettek (HerczyńskiSobotka 2017).

Érdemes részletesebben kitérni Sobotkának (2016) a gimnazjumok falusi vidékeken való bevezetését vizsgáló kutatására, ugyanis ez személetesen mutatja be az országos és helyi szintű oktatáspolitika különbségeit és a decentralizáció hatásait az iskolaszerkezetre. A helyi kontextustól függően nagyon különbözőképpen alakult az intézmény- 
típus sorsa, voltak gminák, ahol a terveknek megfelelően egy önálló gimnazjum jött létre, míg másutt az általános iskolákkal együttmüködő kis intézmények alakultak, tulajdonképpen 9 osztályos általános iskolaként müködve. A kutatásban megvizsgált esetek alapján azokban a gminákban jöttek létre ezek az apróbb kilencosztályos iskolák, ahol erősebb volt a helyi szereplők ellenállása, és a szülők valószínüleg magasabb társadalmi tőkével rendelkeztek. Azokban a gminákban sikerült a reform elképzeléseinek megfelelő, önálló gimnazjumot létrehozni, ahol kisebb ellenállás volt. Bár a reform célja az oktatás minőségének javításával a társadalmi esélyek kiegyenlítése volt, ezt a falvak a mindennapjaikba való túlzott beavatkozásként élték meg, fontosabbnak tartva a helyi intézmény létét, s hogy a gyerekeiknek ne kelljen feleslegesen utazniuk. A negatív reakcióban közrejátszhatott a '70-es években kudarccal végződött tíz évfolyamos általános iskola bevezetése, mely szintén iskola-összevonásokkal akarta az oktatás minőségét javítani, a szülői generáció ennek negatív tapasztalatából is kiindulva utasította el a reformot. Általánosan elmondható, hogy ahol az önkormányzat a reform kezdetekor nem hozott létre önálló gimnazjumot, hanem az általános iskolában indított átmenetileg gimnazjumi osztályokat, ott a szülők kiharcolták hosszú távon az általános iskolával együtt müködő gimnazjum megmaradását.

$\mathrm{A} z$ oktatási rendszer decentralizációjával kapcsolatban Herbst és Wojciuk (2017) kutatása arra hívta fel a figyelmet, hogy a többi visegrádi országhoz képest Lengyelországban az önkormányzatok rendszere kevésbé fragmentált, az önkormányzatok méretéből és nagyobb financiális lehetőségeiből fakadóan hatékonyabban tudták ellátni fenntartói feladataikat. A lengyel decentralizáció sikere Levitas (2018: 7-8) szerint „a döntéshozók azon csoportjának tudatos intézmény- és szervezetépítési stratégiájának eredménye [...], akik az önkormányzatokat az egységes nemzeti közigazgatás részeként látták", és a helyi önkormányzatokat akarták felelőssé tenni a mindennapi közfeladatok ellátására, hogy a kormány a nagy stratégiai kérdésekre és a jogalkotásra tudjon fókuszálni. Hasonló gondolat jelenik meg Śliwerski (2013) ellentétes érvelése mögött, miszerint a lengyel oktatásirányítást a rendszerváltást követő néhány évet leszámítva központosítási törekvések és túlzott állami szabályozás jellemzi.

\section{A kuratoriumok szerepének változásai}

A decentralizációs folyamat formálisan az oktatási intézmények önkormányzati fenntartásba adásával, az 1999-es oktatási reformmal lezárult, ugyanakkor az intézmények feletti pedagógiai-szakmai kontrollt ezt követően is az állam látta el a regionális szintü kuratoriumokon keresztül, melyek az állam helyi képviselőjeként az oktatási minisztérium alá tartoztak. Ugyanakkor a reform során a kuratoriumok és önkormányzatok fenntartói feladatai nem kerültek megfelelően tisztázásra (Herbst et al. 2015), hivatalosan az oktatás szervezése és hátterének biztosítása a fenntartó, míg az oktatás minősége a kuratorium hatáskörébe tartozott.

A kuratoriumok lengyel oktatási rendszerben betöltött feladata és szerepe a rendszerváltás óta jelentős változásokon ment át. Az iskolafenntartás fokozatos decentralizációjával a kuratoriumok szerepe csökkent, az önkormányzatok az iskolák fenntartásával az infrastrukturális háttér biztosítása mellett fokozatosan az oktatás minőségével kapcsolatos feladatokért is felelőssé váltak. 
Az 1991-es oktatási törvény eredeti szövege szerint (Art. 31. Dz.U. 1991 nr 95 poz. 425) a kurator az állami oktatáspolitika vajdasági szintű megvalósításának a vezetője, a feladatai közé tartozik a hozzá tartozó intézmények fenntartása, az iskolanyitások engedélyezése, a beiskolázási körzetek meghatározása és a pedagógustovábbképzések szervezése. A kilencvenes évek során az oktatási rendszerben lezajló decentralizációs folyamatnak köszönhetően a kuratoriumok iskolafenntartói szerepe folyamatosan csökkent, és az 1999-es reform során a középiskolák átadásával meg is szünt.

Az oktatási törvény későbbi változataiban ${ }^{6}$ és a jelenlegi oktatási törvényben a kuratorium feladatai közül a következő elemek maradtak állandóak:

- a pedagógiai felügyelet ellátása;

- az állami oktatáspolitika megvalósítása;

- együttmüködés az önkormányzatokkal a helyi oktatáspolitika irányainak meghatározásában és megvalósításában úgy, hogy az megfeleljen az országos oktatáspolitikai céloknak;

- vajdasági szintű tanulmányi versenyek és vetélkedők szervezése;

- és a vajdaság költségvetésében a tanártovábbképzési források felhasználási módjának kidolgozása. Ez utóbbitt a törvény 2008-as változatában a tanárok szükségleteit vizsgálva, míg a 2016-os törvényben a pedagógiai felügyelet eredményeiből kiindulva valósítja meg.

Mindemellett a kétezres években a kuratoriumok felügyeleti eszközeinek csökkenése figyelhető meg (Herbst-Levitas 2012). Eredetileg a helyi iskolaszerkezeti változások, az intézmények éves terveinek elfogadása és az iskolaigazgatók kinevezése is a kuratorium engedélyéhez volt kötve. A kétezres évek elején a kuratorium döntési jogköre elöször véleményezési joggá változott, majd 2009-től az intézményi tervek és 2011-től az iskolák nyitásának és bezárásának véleményezési joga is megszűnt. 2015-től ezek viszszakerültek a kuratoriumi hatókörbe. A kuratoriumok feladatainak csökkenése az állami szerepvállalás csökkenésére utal, ugyanakkor az interjúkban több interjúalanyom ezzel ellentétes véleményt fogalmazott meg (SZ7; SZ8): szerintük a kilencvenes évek elejét és esetleg a kétezres évek végén pár évet leszámítva az oktatási kormányzatokat az állam szerepének növelésére való törekvés jellemezte.

Az oktatási rendszer minőségi kontrolljában fontos szerepet játszik az 1999-es reform során bevezetett külső vizsgarendszer. Eredetileg felmerült, hogy ezt a feladatot a kuratorium lássa el, azonban végül a kuratoriumi rendszertől független intézményrendszert hoztak létre, amely végig a minisztérium felügyelete alá tartozott: a vizsgák lebonyolítása a nyolc regionális szintű Okręgowe Komisje Egzaminacyjne feladata a központi Centralna Komisja Egzaminacyjnával együttmüködve.

A 2009-től fokozatosan bevezetett új tanfelügyeleti és intézményértékelési rendszer tervezetten szintén önálló intézmény keretében valósult volna meg (M1), végül azonban a kuratorium feladata maradt. Ugyanekkor a kuratoriumok megszüntetése is felmerült, összevonva a tanfelügyeletért és vizsgarendszerért felelös szervezeteket, azonban ez nem jutott túl a belső egyeztetéseken (Mazurkiewicz-Walczak-Jewdokimow 2014). Ezáltal az

6 Az oktatási rendszerről szóló 1991-es törvény 110-szer, míg a 2016-os oktatási törvény eddig 10-szer került módosításra. Az elemzés során ezért az 1991-es törvény 2004-es, 2008-as és 2009-es egységesített változatát, illetve a 2017-es oktatási törvény 2017-es és 2019-es változatát vizsgáltam. 
értékelési feladatok egy új szervezetben központosultak volna, amely a kuratoriumhoz képest jobban el tudott volna különülni a politikától (M1). A kuratoriumban meghatározóak voltak ugyanis a politikai kapcsolatok (M1), amelyek az iskolai értékelésekre és közvetve az igazgató munkájának megítélésre is hatással voltak (SZ5).

A kurator fontos regionális politikai funkció, ugyanis jelentős mértékben tudta befolyásolni a vajdaságban folyó munkát és az állami kontroll mértékét (Herbst-Levitas 2012). Az egymást követő kormányok igyekeztek a saját embereiket kinevezni (Śliwerski 2015), illetve oktatáspolitikai törekvéseinek megfelelően az oktatási minisztérium kuratoriumok feletti kontrollját növelni. Az 1991-es oktatási törvény a kuratoriumok feletti minisztériumi kontroll erősítése céljából kivette a kuratorokat a vajdasági adminisztrációs rendszerből, közvetlenül a minisztérium alá rendelve őket (Levitas-Herczyński 2012), azonban néhány év múlva a decentralizációra hivatkozva a kuratorium feletti kontroll visszakerült a vajdasági hatókörbe (uo.).

Fontos kiemelni, hogy a lengyel közigazgatási rendszerben a vajdasági szintű feladatok egy része önkormányzati, másik részük az államilag kinevezett vajda (wojewoda) hatáskörébe tartozik. 2015 előtt a kurator kinevezéséről és elbocsátásáról a wojewoda döntött az oktatási miniszter engedélyével, vagyis tulajdonképpen áttételesen állami hatókörben volt végig a feladat. A jelenlegi oktatási reform során újra a kuratoriumok szerepének és a kuratorium feletti minisztériumi kontrollnak a növekedése figyelhető meg. A jelenlegi törvényben a kurator kinevezése és elbocsátása az oktatási miniszter felelősségi körébe tartozik. Ugyanezt mutatja a kuratori pályázatot elbíráló bizottság összetétele is. Már az oktatási törvény 2008-as egyik kommentárja is kiemeli a kormány szerepének erősödését a kuratorválasztásban (Pilich 2008), a 2016-os törvényben tovább nőtt a kormány képviselöinek az aránya a bizottságban. Hasonlóan a 2016-os törvény a kuratorhelyettesek kinevezését is miniszteri hatáskörbe utalja, eddig ez a wojewoda feladata volt a kurator javaslatára.

\section{Oktatásfinanszírozás}

Az iskolák fenntartása az önkormányzatok kötelező feladata, melyhez a központi költségvetésből támogatást kapnak. Egy szakértő erről a következőképp fogalmazott: „A decentralizációt kezdeményező reformerek a '90-es évek elején két egymással konfliktusban lévő tényezőt próbáltak kombinálni: egyrészt a helyi önkormányzatok támogatást kapnak az oktatási feladataik ellátásához a központi kormányzattól, másrészt az önkormányzatok autonóm szervezetek" (SZ2). Ennek eredménye, hogy az önkormányzatok a központi költségvetésből kapott szubvenciót nem külön oktatásra szánt támogatásként, hanem az általános központi költségvetésből érkezö öszszeg részeként kapják, és saját szükségleteik, lehetőségeik és prioritásaik alapján döntik el, mekkora összeget szánnak oktatási feladataik ellátására. A központi költségvetés oktatásfenntartási forrásainak önkormányzatok közötti felosztását a 2000-ben bevezetett egységes forrásallokációs algoritmus szabályozza, ami a tanulók számán alapul, a minisztérium által évente megállapított szempontokkal súlyozva.

A központi oktatási szubvenció megállapítása politikai kérdés, mely leginkább az előző évek költségvetési tételéből indul ki, ugyanis ennek összege nem lehet alacsonyabb az előző évinél (SZ2), azonban tervezésekor a hagyomány és nem a mikroszintü finanszírozási feladatok az irányadók (Herbst et al. 2015). A helyi önkormányzatoknak kevés 
lehetőségük van a központi költségvetésből érkezett összeg növelésére. Legfeljebb nyomást gyakorolhatnak a minisztériumra a súlyozás módosítására, azonban ez csak a meghatározott föösszeg felosztásán módosít, így minden változtatásnak vannak vesztesei és győztesei. A föösszeg növelése az oktatási és a pénzügyminisztérium között dől el, melyre a helyi önkormányzatoknak kevesebb a ráhatásuk, ráadásul az oktatási miniszter pozíciója a kormányon belül általában nem a legerősebb (SZ1; SZ2).

Az önkormányzat által a központi költségvetésből az oktatásra kapott források nem célzottak, felhasználásuk az önkormányzattól függ, egy szakértő szerint minden éven van pár tucat olyan önkormányzat, mely a kapott szubvenciónál kevesebbet költ az oktatásra (SZ1). Az új oktatási törvény eredeti szövegében megjelent, hogy az önkormányzatok a központi költségvetésből az oktatásra kapott forrásoknál kevesebbet nem költhetnek az oktatásra (Ustawa $z$ dnia 14 grudnia 2016. r. Prawo Oświatowy, Art 11. Punkt 6), azonban később ezt a pontot törölték.

A z önkormányzatok felelősségi körébe tartozik az oktatás fenntartása és az oktatásra szánt források felhasználásának módja, azonban kevés ráhatásuk van az adóbevételeikre (Herczyński 2012). Éves költségvetésük több mint egyharmada oktatási feladatokat szolgál (Chłoń-Domińczak 2013). A szubvenció összege általában a tanárok fizetését fedezi, bár ez inkább hagyomány, nem jelent meg hivatalos szabályozásként (SZ2). A szubvenció az évek során az önkormányzatok oktatási kiadásainak egyre kisebb részét fedezte (lásd 2. táblázat), a hiányzó összeget az önkormányzatoknak saját forrásokból kellett fedezniük. A 2015-ös reform költségeinek jelentős része is az önkormányzatokra hárult. A z önkormányzatok közül az oktatási feladataik ellátásához arányaiban a nagyvárosoknak és városoknak kell legtöbb saját forrást biztosítaniuk, a kisebb pénzügyi lehetőséggel rendelkező falusi önkormányzatok ugyanis a szubvenció számításakor figyelembe vett falusi szorzó miatt arányaiban jobban finanszírozottak (Raport 2019).

2. táblázat: A szubvenció részaránya az önkormányzatok oktatási kiadásaiban országosan (\%). Saját számolás a Raport 2019 adatai alapján

200420052006200720082009201020112012201320142015201620172018

$\begin{array}{lllllllllllllll}69,5 & 67,5 & 65,3 & 65,0 & 65,3 & 65,0 & 64,1 & 64,4 & 65,1 & 64,7 & 63,0 & 62,8 & 62,9 & 59,7 & 56,7\end{array}$

Az oktatási költségvetés növekedése leginkább a központi tanári fizetésemelésekhez szükséges pluszforrásokhoz köthető, melyre a kétezres években többször sor került, azonban 2012-2018 között nem változott. Az állam és a helyi önkormányzatok közti oktatási feladatok felosztásának tisztázatlanságát mutatja a 2019. április 8-án indult, bérrendezést követelő országos tanári sztrájk is. ${ }^{7} \mathrm{~A}$ sztrájk során az önkormányzatok rendre a tanári bérrendezés mellett foglaltak állást, bár ebben valószínüleg szerepet játszottak a pártpolitikai törésvonalak is, ugyanis a nagyobb városok vezetését az ellenzék adja. A sztrájk hátterében a bérfeszültségek mellett valószínúleg a 2016 óta tartó rendszerszintü átalakítások okozta feszültségek is megjelennek.

Részletesebben írok a sztrájkról itt: http://www.tani-tani.info/a_tobb_napja_tarto_lengyel_tanarsztrajkrol [Letöltve: 2019. 05. 13.] 
Elméletileg a tanári bérek mértékének meghatározása a munkaadó önkormányzatok feladata, azonban a gyakorlatban ez a Karta Nauczycielában a tanári előmeneteli rendszer egyes szintjein meghatározott minimális bért követi (Herbst 2012), kiegészülve a központilag szabályozott (például falusi pótlék az 5000 fö alatti településen tanítók számára), illetve önkormányzatok által meghatározott mértékű pótlékokkal (például a tanított évek száma, a betöltött feladatok alapján). Emellett minden évben meghatározásra kerül a központi költségvetésben az egyes szinteken lévő tanárok átlagbére is, melyet önkormányzatonként is el kell érni. A tanári fizetések jelentős tétele a tanári túlórákból fakad, mely 2017-ben a fizetések 11,6\%-át tette ki (Herbst 2018). A tanári státusz 18 tanítási óra, azonban a tanárok átlagosan 2,3 tanórával többet tanítanak hetente (Herbst 2012).

A fizetések erős központi szabályozásának következménye, hogy ezek országosan kiegyenlítettek. Egy kutatás alapján 2011-ben például a leggazdagabb és legszegényebb gminákban a tanárok átlagbére között csak öt százalék különbség volt (Herbst-Wojciuk 2014). A tanári fizetések értéke nagyban függ az iskola elhelyezkedésétől. Ugyanaz a fizetés, amely egy nagyvárosban - az ottani jövedelmekhez képest - nagyon alacsonynak, a falusias mezőgazdasági fókuszú vidékeken jó fizetésnek számít (SZ2). Ennek eredményeképp a nagyobb városokban egyre nagyobb problémát okoz a tanárhiány, Varsóban például a 2018/2019-es tanévben körülbelül 1600 tanári állás volt betöltetlen. ${ }^{8}$

A lengyel iskolákat alacsony pénzügyi önállóság, ugyanakkor nagyfokú pedagógiai autonómia jellemzi (Herbst et al. 2015). Az iskolák az önkormányzat költségvetési egységeként funkcionálnak, az intézményvezetőknek kevés önálló pénzügyi döntési jogkörük van: a mindennapokban az önkormányzat által elfogadott pénzügyi terv keretein belül rendelkeznek az intézményi forrásokkal. Személyi kérdésekben munkaadóként ők döntenek a tanárok és egyéb munkatársak alkalmazásáról az önkormányzat által meghatározott keretszámoknak megfelelően (Herczyński 2012). A tanárok fizetésére csak a motivációs bónuszokon keresztül van ráhatásuk. Az iskolák bevételei hivatalosan az önkormányzat bevételei, melyeket az önkormányzatok általában az iskola érdekében használnak fel. Pénzügyi függetlenségük önkormányzatonként változó (SZ2), az általam eddig megismert iskolákban az intézményvezetők rendelkeztek az iskola bevételeivel, melyeket leginkább az intézmény infrastrukturális fejlesztésére fordítottak. A fejlesztésekben fontos szerepük van a célzott támogatásoknak és az uniós forrásoknak is.

\section{Iskolabezárások a demográfiai csökkenés és a kuratorium-fenntartó ellentét tükrében}

$\mathrm{A} z$ oktatási feladatok finanszírozásának előbbiekben bemutatott változásai és a diákok számának csökkenése az önkormányzatokat komoly kihívás elé állította. A lengyel oktatási rendszer különösen a kétezres években jelentős demográfiai kihívásokkal nézett szembe, 2002 és 2010 között 28\%-kal csökkent az általános iskolás diákok száma (Federowicz-Sitek 2011). 2010 után a trend nehezebben megbecsülhető, egyrészt a 2004-2010 között született gyerekek száma emelkedni kezdett (Federowicz-Choińska-

https://tvnwarszawa.tvn24.pl/informacje,news,w-stolicy-brakuje-1600-nauczycieli-odchodza-do-lepiejplatnej-pracy,276432.html [Letölve: 2019. 05. 13.] 
Mika-Walczak 2014), másrészt a kétezres évek végén a kormányzat az iskolaköteles kor leszállítására törekedett, de ez folyamatos kudarcokkal és változásokkal került bevezetésre.

A diákok számának csökkenését kisebb mértékben, de követte az iskolák és tanárok csökkenő száma is (Federowicz-Sitek 2011). A demográfiai változások hatásai az országon belüli népmozgások miatt különbözőképpen jelentkeztek. Főként a falvakban okozott problémákat az erősen csökkenő diáklétszám, a nagyvárosokra viszont a diákok számának növekedése jellemző. Az önkormányzatok egy része kivárt, és pluszforrásokat biztosított az oktatási feladatok ellátására, másik része pedig a helyi intézményszerkezet fokozatos vagy azonnali reorganizációja, vagyis egyes intézmények összevonása és bezárása mellett döntött (Kloc 2012). Az intézmények bezárása ugyanakkor sokszor nem járt együtt a tanárok elbocsátásával (Herbst-Levitas 2012). A $z$ iskolaszerkezet meghatározása a fenntartó önkormányzat feladata, azonban 2009 ig a kuratorium engedélye is szükséges volt a helyi iskolastruktúra átalakításához, míg az 2009-től csak véleményezte a kérdést. Sok esetben az iskola megmentéséért öszszefogó szülők - formális vagy informális csatornákon - a kuratoriumokon keresztül is próbálták meggátolni az iskolák bezárását. Kloc tanulmánya alapján (2012) a kuratoriumok 2005-2009 között az intézménybezárások 12 százalékát nem engedélyezték.

$\mathrm{A} z$ iskolák fenntartási költségeinek legnagyobb része a tanárok fizetésére megy el, melyet a Karta Nauczyciela erősen szabályoz, ugyanakkor a magánintézményekre ez nem vonatkozik, ezek a tanárokat a lengyel munka törvénykönyve alapján tudják alkalmazni. Ezt a kiskaput sok önkormányzat kihasználta, és a kis falusi intézmények megszüntetésével egyidőben támogatták vagy informálisan elősegítették, hogy azok helyén alapítványi fenntartású intézmény jöjjön létre (Sadura 2017). Ezek fenntartása olcsóbb, ugyanis bizonyos szabályok, például a Karta Nauczyciela megkötései, a kötelező óraszámra vagy a fizetésre vonatkozó előírások, nem vonatkoznak rájuk. A létező gyakorlatra reagálva 2009-től lehetőség nyílt az ilyen kicsi intézményeket közvetlenül is alapítványi fenntartásba adni (SZ1; SZ6). 2007-2012 között az önkormányzatok több mint 500 intézményt adtak át (Herbst-Herczyński 2015). Ezzel a problémát nem megoldották, hanem csak más problémájává alakították.

\section{Összegzés}

Lengyelországban, hazánkhoz és más posztszocialista államokhoz hasonlóan, a rendszerváltozást követően fontos szerepet kapott a decentralizáció a közigazgatásban és a tanügyigazgatásban is. Ez formálisan, erős állami kontrollal valósult meg, melyet a szükös anyagi erőforrások állami elosztása is erősített. A pénzügyekhez köthető a későbbiekben az önkormányzatok fenntartói szerepének növekedése, melyet segített a kétezres évek második felében az állami oktatáspolitika is. Ez többek közt a kuratoriumok szerepének csökkentésével és az önkormányzatok hatáskörének növelésével járt. Ez a folyamat az utóbbi évtizedben megfordult: a 2015-ben kezdődő strukturális reformot az állami kontrollt újra növelő intézkedések jellemzik. 


\section{IRODALOM}

ChŁoń-Domińczak, A. (2013, ed.) Liczą się efekty. Raport o stanie Edukacji 2012. Warszawa, Instytut Badań Edukacyjnych.

Federowicz, M., Choińska-Mika, J. \& Walczak, D. (2014, ed.) Liczq się nauczyciele. Raport o stanie edukacji 2013. Warszawa, Institut Badań Edukacyjnych.

Federowicz, M. \& Sitek, M. (2011, eds) Społeczeństwo $w$ drodze do wiedy. Raport o stanie edukacji 2010. Warszawa, Institut Badań Edukacyjnych.

GUS (2016) GŁÓWNY URZĄD STATYSTYCZNY Powierzchnia i ludność w prekroju terytorialnym $w 2016$ r. https://stat.gov.pl/files/gfx/portalinformacyjny/ pl/defaultaktualnosci/5468/7/13/1/powierzchnia_i_ludnosc_w_przekroju_ terytorialnym_w_2016_r.pdf [Letölve: 2019.05.29.]

Handke, M. (2015) Poland: Changing the Whole System at Once. Phi Delta Kappan, Vol. 97. No. 3. pp. 34-37. doi: 10.1177/0031721715614826

Herbst, M. (2012) Wynagrodzenia nauczycieli w Polsce - rozwiązania systemowe, dynamika i zróżnicowanie terytorialne. In: M. Herbst (ed.) Finansowanie oświaty. Warszawa, Wydawnictwo ICM Uniwersytetu Warszawskiego. pp. 1-40.

Herbst, M. (2018) Wynagrodzenia nauczycielskie - kto ma rację? https://wiedzadlapolityki. wordpress.com/2018/04/17/wynagrodzenia-nauczycielskie-kto-ma-racje/ [Letölve: 2019. 05. 13.]

Herbst, M. \& Herczyński, J. (2015) Decentralizacja oświaty w Polsce: Doświadczenia 25 lat. In: Bilans zmian instytucjonalnych Polska oświata w okresie transformacji. Warszawa, Instytut Badań Edukacyjnych.

Herbst, M., Herczyński, J., Federowicz, M., Smak, M., Walczak, D. \& Wojciuk, A. (2015) Bilans zmian instytucjonalnych Polska oświata $w$ okresie transformacji. Warszawa, Instytut Badań Edukacyjnych.

Herbst, M. \& Levitas, A. (2012) Decentralizacja systemu oświaty w Polsce 20002010: czas stabilizacji i nowe wyzwania. In: M. Herbst (ed.) Decentralizacja oświaty. Warszawa, Wydawnictwo ICM.

Herbst, M. \& Wojciuk, A. (2014) Przestrzenne nierówności oferty edukacyjnej w zdecentralizowanym systemie oświaty. Przypadek Polski. Edukacja, Vol. 1. No. 126. pp. 34-52.

Herbst, M. \& Wojciuk, A. (2017) Common Legacy, Different Paths: The Transformation of Educational Systems in the Czech Republic, Slovakia, Hungary and Poland. Compare, Vol. 47. No. 1. pp. 118-132. doi: 10.1080/03057925.2016.1153410

Herczyński, J. (2012) Modele decentralizacji oświaty. In: M. Herbst (ed.) Decentralizacja oświaty. Warszawa, Wydawnictwo ICM.

Herczyński, J. \& Sовотка, A. (2017) Organisational models of gymnasium in Poland. Edukacja, Vol. 141. No. 2. pp. 5-31. DOI: 10.24131/3724.170201

KLoc, K. (2012) Konflikty w procesie racjonalizacji sieci szkół. In: A. Levitas (ed.) Strategie oświatowe. Warszawa, Wydawnictwo ICM.

Kurzyna-Chmiel, D. (2018) Główne obszary rozwoju oświaty samorządowej od początku lat 90-tych poprzedniego wieku. Studia z teorii wychowania, Vol. IX. No. 4 (25). pp. 5570 .

Levitas, A. (2018) Local Government Reform as State Building: What the Polish Case Says about "Decentralisation". Zarzadzanie Publiczne Public Governance, Vol. 45. No. 3(45).pp. 5-25. DOI: 10.15678/ZP.2018.45.3.01 
Levitas, A. \& Herczyński, J. (2002) Decentralization, Local Governments and Education Reform in Post Communist Poland. In: K. J. Davey (eds): Balancing National and Local Responsibilities. Education Management and Finance in Four Central European Countries. Budapest, OSI. pp. 113-189.

Levitas, A. \& Herczyński, J. (2012) Decentralizacja systemu oświaty w Polsce. Lata 1990-2000 - tworzenie systemu. In: M. Herbst (ed.) Decentralizacja oświaty. Warszawa, Wydawnictwo ICM.

Mazurkiewicz, G., Walczak, B. \& Jewdokimow, M. (2014) Implementation of a New School Supervision System in Poland. OECD Education Working Paper, No. 111. DOI: http://dx.doi.org/10.1787/5jxrlxrxgc6b-en

Pilich, M. (2008) Ustawa o systemie oświaty - komentarz. 2. wydanie. Warszawa, Wolters Kluwer Polska.

Pilich, M. \& Olszewski, A. (2018) Prawo Oświatowe oraz przepisy wprowadzające Komentarz. Warszawa, Wolters Kluwer Polska.

Raport (2019) Raport o finansowaniu oświaty w Polsce w latach 2004-2018. http://www. funduszeunijne.zgwrp.org.pl/attachments/article/1476/Raport.pdf [Letölve: 2019. 05. 13.]

Sadura, P. (2017) Państwo, szkoła, klasy. Warszawa, Wydawnictwo Krytyki Politycznej.

Śliwerski, B. (2013) Diagnoza uspołecznienia publicznego szkolnictwa III RP w gorsecie centralizmu. Kraków Oficyna Wydawnicza „Impuls”.

Śliwerski, B. (2015) Analiza polityki oświatowej wobec pozoru demokracji w szkolnictwie publicznym. Rocznik Pedagogiczny, Vol. 38. pp. 9-29.

Sовотка, A. (2016) Trudności we wprowadzaniu reformy gimnazjalnej na obszarach wiejskich. Edukacja, Vol. 3. No. 138. pp. 75-97.

Sucheска, J. (2016) Jego badania stały się dla minister Zalewskiej podstawą do likwidacji gimnazjów. Nam mówi: "Nikt mnie o zdanie nie pytał". Gazeta Wyborcza, 2016. október 23.

Szydıo, B. (2015) Exposé premier Beaty Szydło - stenogram. https://www.premier.gov.pl/ expose-premier-beaty-szydlo-stenogram.html [Letölve: 2019. 05. 13.]

Zahorska, M. (2016) Nieznośna lekkość... reformowania oświaty. Studia z Polityki Publicznej, Vol. 10. No. 2. pp. 43-64.

A cikk a Creative Commons Attribution 4.0 International License (https://creativecommons.org/licenses/ by/4.0/) feltételei szerint publikált Open Access közlemény, melynek szellemében a cikk bármilyen médiumban szabadon felhasználható, megosztható és újraközölhető, feltéve, hogy az eredeti szerző és a közlés helye, illetve a CC License linkje és az esetlegesen végrehajtott módosítások feltüntetésre kerülnek. (SID_1) 